\title{
Pencarian Dasar-dasar Filoso
bagi Keberadaan Filsafat Nusantara
}

\author{
Ganang Dwi Kartika
}

\begin{abstract}
The meaning of philosophy in Indonesian has become an interesting topics, especially when it is related to another concept, culture. Some Indonesian dictionary writers defined "filsafat" (philosophy) in many ways from different aspects. However, the definitions have not reflected the meaning accuracy, both from the linguistic pattern aspect and from its terminology. Besides that, the definitions, which come from Western, invite another question. If there is Western philosophy, then what about Eastern philosophy, especially Nusantara philosophy? That question is also discussed in this writing.
\end{abstract}

KatA KunCI Istilah, batasan/definisi, filsafat Barat.

Pertanyaan “Apakah filsafat Jawa, Sunda, Batak, Minang, dan lain-lain itu ada?" jelas bukan merupakan pertanyaan yang remeh, yang sederhana, melainkan dapat menjadi satu pertanyaan yang berpotensi menggugat keyakinan pada, khususnya, orang Jawa yang terlanjur berkeyakinan dan bangga akan keyakinannya bahwa filsafat Jawa itu bukan sekadar ada, tetapi bernilai adiluhung. Karena itu, pertanyaan tersebut merupakan pertanyaan yang eksistensial bagi filsafat Jawa yang terlanjur diyakini keberadaannya.

Keyakinan mereka bahwa filsafat Jawa itu ada memang beralasan. Setidaktidaknya beberapa buku yang mengusung pemikiran-pemikiran Jawa telah diterbitkan dengan diberi label filsafat oleh penulisnya, misalnya Etika Jawa: Sebuah Analisa Falsafi tentang Kebijaksanaan Hidup Jaroa yang ditulis oleh Frans Magnis-Suseno, S.J. (1984) dan Filsafat Jazva oleh dr. Abdullah Ciptoprawiro (Jakarta: Balai Pustaka, 1986). Namun, pertanyaan yang bernada kesangsian itu tidak cukup dijawab dengan menunjukkan bukti-bukti keberadaan filsafat Jawa dalam bentuk buku dan berakhir dengan tindakan tersebut. Bahwa keberadaan buku itu penting memang tak dapat dimungkiri, tetapi lebih dari itu memang diperlukan penjelasan yang rinci 
yang membuat orang mengerti bahwa filsafat Jawa, Sunda, Batak, Minang, dan suku-suku lainnya memang layak dan bahkan perlu ada. Tulisan ini ingin menunjukkan bahwa keberadaan filsafat Nusantara memang sudah saatnya memperoleh pengakuan dengan satu catatan bahwa masing-masing perlu menunjukkan apa yang menjadi perhatiannya dan bagaimana orientasi pemikirannya itu.

Untuk tujuan tersebut satu hal yang mendesak untuk dipikirkan kembali adalah menengok kembali arti kata filsafat itu sendiri di awal kelahirannya dan bagaimana perkembangan makna pada dirinya serta bagaimana filsuf itu sendiri memaknai filsafat. Penting juga diamati bagaimana pemahaman yang telah terjadi pada orang awam tentang filsafat itu sendiri dewasa ini.

\section{Lahirnya Filsafat dan Semangat yang Menjiwainya}

Ditinjau dari segi sejarah kelahirannya, filsafat Barat yang sangat populer dewasa ini di Indonesia merupakan pemberontakan terhadap cara berpikir kuno di Yunani Purba kira-kira 26 abad SM. Cara berpikir kuno yang dimaksud adalah cara berpikir yang menempatkan mythos (Yunani), yang dalam bahasa Inggris disebut dengan myth dan yang diberi definisi nominal dengan 'fable', 'tale', 'legend', 'talk', 'speech', 'conversation', 'rumor', 'anything delivered by word of mouth' (Angeles 1981: 182). Semua itu dipandang sebagai acuan (sumber) berpikir dan bahkan diterima sebagai ukuran kebenaran menyangkut apa pun pertanyaan orang Yunani Kuno tentang alam semesta dan bahkan keberadaan dirinya sendiri. Dengan demikian, dasar kebenaran akan segala sesuatu bukan terletak pada diri manusia sendiri sebagai makhluk yang berpikir dan dengannya mencari tahu melalui kemampuan manusiawi di dalam dirinya. Cara berpikir demikian dinilai lemah karena mengandalkan keyakinan, tidak bersifat kritis, dan tidak membuka kemungkinan tafsir lain yang sebenarnya dapat mengantarkan pada level kebenaran yang lebih tinggi dari yang sudah ada dan yang sudah berlaku sekali pun.

Pemberontakan yang dilanjutkan dengan penolakan terhadap penjelasan yang bersifat mitologis diakui menjadi tonggak perubahan berpikir Yunani Kuno yang berdampak amat besar kepada peradaban Barat secara keseluruhan. Dengan tumbangnya dominasi mythos atas kenyataan hidup sehari-hari muncullah paradigma berpikir baru yang bertumpu pada pengamatan inderawi dan penalaran yang bersifat kefilsafatan yang selanjutnya disebut logos (kata [tuturan, bahasa] maupun juga rasio). Dengan demikian, logos melampaui rasio atau akal budi tetapi tidak terlepas darinya (Bertens 1992: 16-18).

Yang dimaksud dengan penalaran kefilsafatan di atas adalah bahwa terhadap hasil pengamatannya sejumlah kecil orang-orang Yunani berusaha menemukan apa yang disebut arkhe 'asas; prinsip dasar; sesuatu yang hakiki di balik penampakan suatu benda melalui akal budinya sendiri' (Bertens 1992: 26-32). Untuk berpikir demikian, sudah tentu diperlukan kemampuan melakukan abstraksi pada diri yang bersangkutan dan dengan 
itu cenderung untuk menghasilkan pemikiran yang spekulatif, tak terbatas, melampaui yang fisik atau yang nampak.

Sejarah filsafat Barat juga membuktikan bahwa kelahiran seseorang menjadi seorang filsuf tidaklah mudah, dalam arti bahwa diperlukan kemampuan kerohanian yang luar biasa (akal budi) dan ketajaman dalam melihat persoalan dan dalam mengajukan pertanyaan mendasar yang dengannya persoalan makin dikaji lebih mendalam, menuju arah yang lebih benar. Lebih daripada semua itu, seorang filsuf dituntut untuk mampu mengemukakan argumentasi yang tidak saja masuk akal, tetapi juga melampaui argumentasi yang pernah ada berkaitan dengan sesuatu persoalan yang sama, misalnya. Penting digarisbawahi bahwa filsafat tidak dapat dilepaskan dari arti penting rasio, tetapi lebih daripada itu.

Perkembangan terakhir filsafat Barat menunjukkan kecenderungan yang jauh berbeda dibandingkan tahapan-tahapan yang mendahuluinya. Jika di masa Yunani perhatian lebih tertuju pada persoalan bahan dasar alam semesta (kosmologis, kosmosentris) (Windelband I 1958: 27-65), sejak masa Sokrates, terutama, perhatian besar diberikan kepada manusia (antroposentris, antropologis) (Windelband I 1958: 66-98), menggantikan alam (kosmos). Pergeseran perhatian filsuf lagi-lagi terjadi di Abad Pertengahan ketika gereja menunjukkan dominasinya atas kehidupan. Pada saat ini manusia, yang semula menduduki posisi sentral sebagai pusat dunia, digantikan oleh kemahakuasaan Tuhan (teosentris, teologis) atas semua yang ada, termasuk diri manusia (Windelbang I 1958: 210 - 262). Pada masa modern, mulai abad ke-17 yang populer dengan sebutan Renaissance (kelahiran kembali), manusia kembali "ditemukan" (Windelband II 1958: 352-377) hingga akhirnya persoalan bergeser lagi pada abad ke-20 ini kepada persoalan yang tak dapat dilepaskan dari seluruh keberadaan manusia, yakni mempersoalkan bahasakhususnya dalam filsafat bahasa atau analisis bahasa.

Jika pada mulanya filsafat terus berkutat pada pertanyaan metafisik yang berpretensi untuk mengetahui berbagai hal yang melampaui fisik, filsafat pun kemudian bergeser menuju satu pendirian yang justru menentang kecenderungan lama itu dengan menyatakan bahwa analisis bahasa merupakan metode yang tepat bagi filsafat karena semua permasalahan filsafat dapat diselesaikan dengan analisis bahasa (Bagus 1992: 19). Pernyataan Ludwig Wittgenstein berikut ini mencerminkan perkembangan baru dalam hal peranan dan fungsi filsafat bagi kehidupan, yaitu Alle Philosophie ist Sprachkritik (setiap filsafat adalah kritik atas bahasa) (Bertens 1990: 17).

Hal penting yang selanjutnya patut dikemukakan adalah bahwa dengan perubahan-perubahan tersebut, terlihat cara pandang filsafat yang bersifat kritis. Sikap ini tidak hanya ditujukan kepada pihak lain di luar dirinya, tetapi juga kepada dirinya sendiri. Hal lain yang perlu digarisbawahi pula dari uraian di atas adalah bahwa filsafat Barat menempatkan unsur rasional sebagai bagian penting dalam kegiatan yang bersifat kefilsafatan. Hal ini penting sebagai dasar untuk memahami argumen tentang mengapa filsafat 
Jawa cenderung dipertanyakan ketika istilah filsafat dilekatkan kepada dirinya. Karena itu, tinjauan ringkas tentang pengertian di balik istilah filsafat penting.

\section{Persoalan Terminologi dan Pemaknaannya dalam Kamus Bahasa}

Berikut ini dikemukakan beberapa temuan sehubungan dengan istilah apa yang digunakan di dalam tiga kamus bahasa, yaitu Kamus Umum Bahasa Indonesia (Poerwadarminta 1984: 280, 282), Kamus Indonesia-Inggris: An Indonesian-English Dictionary (Echols dan Shadily 1990: 162-165) dan Wörterbuch Indonesisch-Deutsch (Krause 1985: 89-90) sekadar untuk memberikan gambaran sekalipun cukup terbatas.

\section{TABEL 1}

KATA-KATA YANG SEKELUARGA DENGAN FILSAFAT DAN KELAS KATANYA

\begin{tabular}{|l|l|l|l|l|}
\hline Kamus Jenis Kata & Kata Benda & Kata Kerja & Kata Sifat & $\begin{array}{l}\text { Kata Ganti } \\
\text { Orang (Profesi) }\end{array}$ \\
\hline Kamus Umum & falsafat & berfalsafat & falsafi & ahli falsafat \\
Bahasa Indonesia & falsafah & - & - & - \\
Poerwadarminta & filsafat & - & filosofis & filsuf \\
\hline Kamus Umum & falsafah & berfalsafah & filosofis & filosof \\
Bahasa Indonesia & filsafat & - & - & - \\
Badudu-Zain & filosofi & - & - & filsuf \\
\hline Indonesia-Inggris & filosofi & - & filosofis & failasuf \\
Echols-Shadily & falsafah & berfalsafah & falsafi & filusuf \\
& falsafat & berfalsafat & - & - \\
& filsafah & - & - & - \\
& filsafat & - & filsafati & filsuf \\
& filsafat & berfilsafat & kefilsafatan & - \\
\hline Inggris-Indonesia & - & - & filosofis & - \\
Echols-Shadily & falsafat & - & - & filsuf \\
\hline Indonesisch- & filosofi & - & - & ahli filsafat \\
Deutsch Krause & filsafat & berfilsafat & falsafi & ahli pikir \\
\hline Jerman-Indonesia & - & - & - & \\
Heuken, S.J. & - & - & & \\
& - & & &
\end{tabular}

Dari tabel tersebut dengan mudah dilihat betapa beragamnya istilah yang dipakai dalam bahasa Indonesia untuk satu kata yang dewasa ini populer disebut dengan filsafat. Kerancuan segera dapat dibayangkan apalagi jika ditelusuri lebih jauh lagi arti yang diberikan kepada tiap-tiap kata yang didefinisikan atau kata-kata yang mendefinisikan. Berikut ini dipaparkan bukti kerancuan (ketumpangtindihan) pengertian dari berbagai kamus bahasa. 
TABEL 2

VARIAN KATA FILSAFAT PADA KAMUS BAHASA INDONESIA DAN MASALAH YANG DITIMBULKANNYA

\begin{tabular}{|c|c|c|c|}
\hline $\begin{array}{l}\text { Varian } \\
\text { Kata }\end{array}$ & Sumber & $\begin{array}{l}\text { Bersinonim } \\
\text { dengan }\end{array}$ & Catatan mengenai Makna/Padanan Kata \\
\hline filsafat & & falsafah & $\begin{array}{l}\text { Makna rancu karena filsafat (bersifat kritis) } \\
\text { berbeda dari falsafah (dogmatis-ideologis) }\end{array}$ \\
\hline filsafah & $\begin{array}{l}\text { Indonesia-Inggris } \\
\text { Echols-Shadily }\end{array}$ & filsafat & $\begin{array}{l}\text { Diberi padanan kata dalam bahasa Inggris } \\
\text { Inggris philosopliy, 'ideology'. Kata filsafal } \\
\text { menambah perbendaharaan kata bagi filsafat, } \\
\text { tetapi berpotensi menambah keruwetan } \\
\text { peristilahan. Makna rancu karena menyamakan } \\
\text { dua hal: 'philosopliy' bersifat terbuka, sedangkan } \\
\text { 'ideology' tertutup }\end{array}$ \\
\hline falsafat & Poerwadarminta & falsafah & $\begin{array}{l}\text { 'Pengetahuan dan penyelidikan dengan akal } \\
\text { budi mengenai sebab-sebab, asas-asas, hukum, } \\
\text { dsb., dapat segala yang ada dalam alam } \\
\text { semesta ataupun mengenai kebenaran dan arti } \\
\text { adanya sesuatu' }\end{array}$ \\
\hline falsafah & Badudu-Zain & filsafat, & $\begin{array}{l}\text { Makna rancu karena filsafat dan filosofi berbeda } \\
\text { filosofi secara mendasar dari falsafah. Filsafat, yang } \\
\text { sebenarnya bersinonim dengan filosofi ternyata } \\
\text { diberi arti berbeda. Filsafat 'pengetahuan dan } \\
\text { pemikiran tentang kebenaran dan tentang arti } \\
\text { keberadaan sesuatu', sedangkan filosofi } \\
\text { 'pandangan tentang kehidupan (bagaimana kita } \\
\text { melihat kehidupan ini)' }\end{array}$ \\
\hline filosofi & Poerwadarminta & falsafat & $\begin{array}{l}\text { Penggunaan dan penyepadanan arti filsafat filsafat } \\
\text { dengan filosofi masih dapat diterima, tetapi } \\
\text { menyamakan keduanya dengan falsafat } \\
\text { berpotensi menambah kerancuan karena } \\
\text { terdapat kecenderungan pada kamus-kamus } \\
\text { yang ada seolah-olah akhiran /-h/dapat } \\
\text { dipertukarkan begitu saja dengan /-t/ sehingga } \\
\text { falsafat dapat dibaca sebagai falsafah, padahal } \\
\text { arti keduanya berbeda. }\end{array}$ \\
\hline
\end{tabular}

Berikut ini dipaparkan kerancuan yang terjadi pada kata filsuf dari kamuskamus yang dijadikan sebagai objek pengamatan. Dari kamus-kamus yang diamati, ternyata kerancuan hanya terjadi pada Kamus Umum Balıasa Indonesia yang ditulis Prof. Dr. J.S. Badudu dan Prof. Sutan Mohammad Zain (1994: 403) dan Kamus Jerman-Indonesia oleh Adolf Heuken, S.J. (1987: 370).

TABEL 3

KERANCUAN MAKNA KATA FILSUF

DALAM KAMUS BAHASA INDONESIA

\begin{tabular}{|l|l|l|l|}
\hline $\begin{array}{l}\text { Varian } \\
\text { Kata }\end{array}$ & Sumber & $\begin{array}{l}\text { Bersinonim } \\
\text { dengan }\end{array}$ & Catatan mengenai Makna/Padanan Kata \\
\hline filsuf & Badudu-Zain & filosof & $\begin{array}{l}\text { Makna rancu karena keduanya diberi arti yang } \\
\text { sama, yaitu 'ahli pikir, ahli ilmu filsafat,' } \\
\text { padahal ahli pikir (setara dengan filsuf) berbeda } \\
\text { dengan ahli ilmu filsafat (mereka yang menguasai } \\
\text { pemikiran para filsuf) }\end{array}$ \\
\hline $\begin{array}{l}\text { ahli } \\
\text { filsafat }\end{array}$ & Heuken, S.J. & $\begin{array}{l}\text { filsuf } \\
\text { ahli pikir } \\
\text { rancu karena ahli filsafat disamakan dengan filsuf } \\
\text { (lihat penjelasan di atas) }\end{array}$ \\
\hline
\end{tabular}


Hal-hal penting yang perlu digarisbawahi di sini berdasarkan ketiga tabel di atas adalah bahwa (a) peristilahan yang berkaitan dengan filsafat sesuai dengan kelas katanya masing-masing cenderung berlebihan. Karena itu, jika semua itu pada akhirnya menimbulkan kebingungan, perlu dilakukan penyederhanaan; (b) Kerancuan arti/makna kata masih banyak ditemukan, misalnya filsafat diseartikan dengan falsafah dan tidak dibedakan dari ideologi, misalnya; (c) untuk menghindari kerancuan penggunaan istilah yang berdampak pada pemahaman arti kata, perlu dilakukan reduksi dalam hal kata-kata yang telah digunakan selama ini agar di masa depan kesimpang-siuran dapat dikurangi.

Tanpa bermaksud "memiskinkan" kekayaan bahasa Indonesia, kesalahkaprahan peristilahan di dalam dunia filsafat perlu diluruskan dengan mengajukan alternatif berikut ini untuk mengurangi kekacauan pemahaman yang berpotensi melahirkan kebingungan di dalam diri pembaca kamus dan orang yang sedang mempelajari filsafat itu sendiri, menyangkut persoalan istilah mana yang sebaiknya dipakai, apakah ada perbedaan mendasar satu dengan lainnya.

TABEL 4

USULAN PENYEDERHAAN PERISTILAHAN FILSAFAT DAN KELAS KATANYA

\begin{tabular}{|l|l|l|l|l|}
\hline Varian Kata & Kata Benda & Kata Kerja & Kata Sifat & Kata Ganti Orang (Profesi) \\
\hline $\begin{array}{l}\text { falsafah } \\
\text { falsafat } \\
\text { filsafat } \\
\text { filosofi } \\
\text { berfalsafat } \\
\text { berfalsafat } \\
\text { berfilsafat }\end{array}$ & $\begin{array}{l}\text { filsafat } \\
\text { filosofi }\end{array}$ & & & filsuf \\
falsafi & & berfilsafat & & \\
filosofis & & & & \\
filsafati & & filsafati & \\
kefilsafatan & & kefilsafatan & \\
ahlifalsafat & & filosofis & \\
filsuf & & & \\
filosof & & & \\
failasuf & & & filsuf \\
filusuf & & & filosof \\
ahli filsafat & & & ahli pikir \\
ahli pikir & & & & ahli filsafat (hanya \\
& & & & berlaku untuk mereka \\
& & & & filsafat sebagai ilmu) \\
\hline
\end{tabular}

Penyederhanaan di atas sebenarnya masih dapat dilakukan lebih lanjut, misalya untuk menunjuk pada 'pelaku' lebih baik digunakan istilah filsuf alih-alih filosof atau ahli pikir walaupun ketiga istilah itu boleh saja digunakan karena artinya pada dasarnya sama. Pertimbangannya adalah menyangkut kelaziman, ekonomi bahasa, dan variasi pembentukan kata yang jauh lebih lengkap. Ahli filsafat tidak dapat disamakan dengan ahli pikir dan filsuf karena mengandung pengertian yang berbeda: seorang filsuf atau ahli pikir belum tentu ahli filsafat, walaupun beberapa di antaranya 
ada yang demikian; ahli filsafat juga belum tentu seorang filsuf karena ia "hanya" menguasai pemikiran-pemikiran yang ada di dalam sejarah filsafat tertentu. Padahal, kategori sebagai seorang filsuf adalah sejauh seseorang diakui oleh para ahli filsafat dan filsuf lain bahwa dirinya telah menghasilkan suatu pemikiran filosofis dalam hal tertentu.

Kata filsafat, dengan argumen yang sama dengan di atas, lebih baik digunakan daripada filosofi atau pemikiran karena tidak semua pemikiran adalah filsafat. Falsafah tidak dapat disamakan dengan filsafat karena ia mengacu pada pandangan hidup pribadi (orang atau bangsa) yang cenderung tidak dapat diganggu gugat, padahal semangat/jiwa filsafat justru 'kritis' ('tidak dogmatis').

Kata filsafati sebenarnya lebih baik digunakan daripada filosofis atau bersifat kefilafatan, tetapi ketiga kata tersebut cukup diminati oleh para penulis buku filsafat dalam edisi bahasa Indonesia sehingga satu dengan yang lainnya masih mungkin untuk dipertukarkan, sesuai dengan pilihan dan pertimbangan setiap penulis. Kata falsafati lebih baik tidak digunakan dalam arti filsafati karena cenderung berkaitan dengan falsafah dengan pengertian sebagaimana telah dinyatakan, demikian juga dengan falsafi.

Kata berfilsafat dengan sendirinya seharusnya digunakan untuk menggantikan berfalsafah atau berfalsafat dan tidak dapat disamaartikan dengan 'kegiatan berpikir' yang umum dilakukan oleh manusia, kecuali dengan memenuhi kriteria tertentu sebagaimana dipaparkan di bagian berikut ini.

\section{Arti Filsafat menurut Kamus Filsafat}

Mengingat kata filsafat mengandung pengertian teknis, definisi kata tersebut dengan berdasarkan kamus filsafat amatlah penting. Dengan cara ini kita dapat mengetahui adakah perbedaan yang (cukup) mendasar dalam pemahaman umum berkaitan dengan keberadaan dan penggunaan istilah itu.

Istilah tersebut dalam Dictionary of Philosophy yang ditulis Peter A. Angeles (1981: 211) berasal dari bahasa Yunani philosophia yang jika dilihat secara etimologis berasal dari dua kata, yaitu philos yang berarti 'love' atau philia yang berarti 'friendship' (persahabatan), 'affection' (kasih sayang, cinta), 'affinity for' (simpati kepada), 'attraction toward' (ketertarikan pada), dan sophos yang berarti 'a sage' (seorang yang arif, cerdas), 'a wise one' (seorang yang bijaksana) atau sophia yang berarti 'wisdom' (kebijaksanaan), 'knowledge' (pengetahuan), 'skill' (kecakapan, kepandaian), 'practical wisdom of experinece' (kebijaksanaan atau pengalaman yang berguna), 'intelligence' (intelegensi, kecerdasan). Sering pengertian dasar yang dikenakan pada filsafat bersifat reduktif, dalam arti hanya mengatakan sebagian dari keseluruhan, seperti 'cinta akan kebijaksanaan.' Padahal, sebagaimana kita ketahui, di balik kata kebijaksanaan (sophos) itu masih terdapat arti lain yang dilekatkan kepadanya, di antaranya pengetahuan, intelegensi, dan pengalaman yang berguna. 
Angeles (1981: 211) lebih lanjut menyatakan bahwa kata filsafat "has as many meanings as philosophers enganing in it." Walaupun demikian, dikemukakan juga pengertian dasar yang terkandung di dalamnya, yaitu '(1) the speculative attempt to present a systematic and complete view of all reality (upaya spekulatif untuk menyajikan suatu pandangan sistematik serta lengkap tentang seluruh realitas), (2) the attempt to describe the ultimate and real nature of reality (upaya untuk melukiskan hakikat akhir/ tertinggi dan dasar yang nyata dari realitas), (3) the attempt to determine the limits and scope of our knowledge: its source, nature, validity, and value (upaya untuk menentukan batas dan jangkauan pengetahuan: sumber, hakikat keabsahan dan nilainya), (4) the critical inquiry into the presuppositions and claims made by the various fields of knowvledge (penilaian kritis atas pengandaian dan pernyataan yang diajukan oleh berbagai bidang pengetahuan), (5) the dicipline which tries to help you "see" what you say and to say what you "see" (disiplin ilmu yang berupaya untuk membantu melihat apa yang kita katakan dan untuk mengatakan apa yang kita lihat.

Sejalan dengan Angeles, Bagus (1996: 243) menyatakan bahwa di balik arti harfiah filsafat itu, yaitu 'cinta akan kebijaksanaan,' terkandung suatu maksud atau pengertian bahwa manusia sesungguhnya tidak pernah sampai pada pengertian yang bersifat menyeluruh dan sempurna tentang segala sesuatu yang apa yang dimaksudkan dengan kebijaksanaan itu. Karena cintanya itu, "semangat" yang seharusnya tertanam di dalam diri manusia adalah bahwa ia harus secara terus-menerus mengejarnya. Jika ditinjau dari sisi lain, yakni dari segi isi pengertian (apa yang dilakukannya), sebagaimana yang dinyatakan Bagus, filsafat adalah suatu "... pengetahuan yang dimiliki rasio manusia yang menembusi dasar-dasar terakhir dari segala sesuatu. Filsafat menggumuli seluruh realitas, tetapi teristimewa eksistensi dan tujuan manusia."

Rumusan Bagus tersebut dalam khasanah filsafat Barat ditempatkan sebagai salah satu di antara banyak rumusan tentangnya, sebagaimana diperlihatkan melalui beberapa contoh definisi yang sesungguhnya amat banyak di dalam khazanah filsafat Barat sejak dahulu hingga sekarang berikut ini.

\section{Beberapa Definisi Filsafat menurut Para Filsuf}

Berikut ini dikutipkan beberapa saja dari definisi filsafat yang banyak ditemukan di berbagai buku filsafat. Pada kesempatan ini definisi yang diperlukan-sekadar sebagai ilustrasi akan adanya pergeseran dan pemahaman yang berbeda-beda-diambil dari buku Filsafat Para Filsuf Berfilsafat yang ditulis Gerard Beekman dan R.A. Rivai (1984: 14-24)sebagai berikut.

Menurut Bertrand Russell, "Filsafat tidak lebih dari usaha untuk ... menjawab pertanyaan-pertanyaan terakhir, tidak secara dangkal atau dogmatis seperti yang kita lakukan pada kehidupan sehari-hari dan bahkan dalam ilmu pengetahuan, namun secara kritis, dalam arti setelah diselidiki 
problem apa yang dapat ditimbulkan oleh pertanyaan-pertanyaan yang demikian dan setelah kita menyadari segala kekaburan dan kebingungan, yang menjadi dasar bagi pengertian kita sehari-hari..."

Menurut R. Beerling, "Filsafat adalah pemikiran yang bebas, diilhami oleh rasio, mengenai segala sesuatu yang timbul dari pengalaman-pengalaman."

Menurut Alfred Ayer, "Filsafat adalah pencarian akan jawaban atas sejumlah pertanyaan yang sudah semenjak zaman Yunani dalam hal-hal pokok tetap sama, pertanyaan mengenai apa yang dapat kita ketahui dan bagaimana kita dapat mengetahuinya; hal-hal apa yang ada dan bagaimana hubungannya satu sama lain. Selanjutnya dipermasalahkan pendapat-pendapat yang telah diterima, dicari ukuran-ukuran, dan diuji nilainya; apakah asumsi-asumsi dari pemikiran itu dan selanjutnya memeriksa apakah hal-hal itu berlaku."

Menurut Corn Verhoeven, "Filsafat adalah meradikalkan keheranan ke segala jurusan."

Menurut R. Kwant, "Berfilsafat yang sebenarnya adalah menguji secara kritis akan kesemestian sesuatu yang dianggap sudah semestinya."

Dari definisi-definisi tersebut, kita mengetahui bahwa setiap filsuf memberikan definisi yang berbeda-beda untuk menjelaskan filsafat. Artinya tidak ada satu pun definisi yang harus dianggap benar dan paling tepat untuk menyatakan filsafat itu apa. Tampaknya status sebagai seorang filsuf memberi keleluasaan baginya untuk menyatakan pendapat tentangnya.

Sekalipun pendapat tersebut beragam, keberadaan filsafat barat tidak lepas dari upaya untuk memberikan jawaban atas pertanyaan terakhir yang mendasar, yang didasarkan pada pemikiran rasional yang bebas, dan bertumpu pada semangat kesangsian yang radikal atas segala sesuatu, yang tidak lain untuk mendapatkan kebenaran yang senantiasa baru.

Sebagai bahan renungan, perlu kita simak definisi lain dari Bertnand Russell yang kiranya dapat menambah wawasan dan menimbulkan tambahan kepercayaan diri bagi eksistensi Filsafat Jawa di kemudian hari:

"Filsafat...adalah sesuatu yang terletak di antara teologi dan ilmu pengetahuan eksakta. Seperti teologi, filsafat ini terdiri dari spekulasi-spekulasi tentang hal-hal, mengenai apa yang sampai sekarang belum dapat diperoleh pengetahuan yang definitif; namun dengan ilmu pengetahuan eksakta ia mempunyai persamaan, bahwa ia lebih mengutamakan daya pikir manusia... Antara teologi dan ilmu eksakta terbentang semacam daerah tak bertuan, yang terbuka bagi serangan dari kedua belah pihak; dan daerah tak bertuan ini adalah lapangan dari filsafat..." (terjemahan oleh Beekman dan R.A. Rivai 1984: 22)

\section{Definisi Filsafat dan Persoalan di Baliknya}

Definisi-definisi yang telah dipaparkan terdahulu kiranya cukup dapat memberikan gambaran secara ringkas tentang apa dan bagaimana filsafat itu. Sekalipun definisi yang diturunkan dari kamus cenderung bersifat nominal atau sinonim semata, namun kita telah memperoleh gambaran pasti tentang kata manakah yang lazim digunakan oleh para penyusun kamus 
dan oleh siapa pun yang berkepentingan dengan filsafat.

Jika kita runut kembali, pendefinisian filsafat secara etimologis, yaitu terdiri atas philos/philia ('cinta') dan sophos/Sophia ('kebijaksanaan') sehingga diartikan sebagai 'cinta akan kebijaksanaan,' termasuk ke dalam definisi nominal. Ditinjau dari sudut pandang logika, pendefinisian demikian (definisi nominal) belum memenuhi syarat sebagai sebuah definisi yang benar dan ideal (definisi hakiki). Walaupun demikian, cara ini masih sering digunakan dengan maksud sekadar untuk mengenali arti dasarnya. Alasannya adalah definisi ini dapat memberikan ilustrasi sederhana tentang awal kelahiran filsafat dan semangat yang dahulu mendasarinya.

Titik tolak pendefinisian yang kedua adalah definisi yang didasarkan pada pemahaman dari tiap-tiap filsuf itu sendiri. Definisi yang demikian cenderung menghasilkan banyak definisi, bahkan dapat sebanyak jumlah filsuf itu sendiri. Dasar pendefinisian seperti ini memang akan menjadi tak lebih dari "pendapat" yang dalam terminologi Plato bersifat subjektif belaka atau hanya berada dalam tataran individual (filsuf). Persoalannya memang bukan hanya sebatas itu.

Filsafat itu memang berakar pada kebebasan, pada rasionalitas, sedangkan kebebasan itu berada di dalam diri setiap filsuf, dan hakikat rasionalitas itu adalah keragaman, bukan keseragaman. Watak dan semangat filsafat itu sendiri, yang dengannya filsafat lahir, tumbuh, dan berkembang ibarat panah yang melesat dari busurnya: semakin cepat dan senantiasa berada dalam gerak yang meninggalkan "induk"-nya (busur itu). Jika yang terjadi kemudian di dunia Barat filsafat cenderung penuh diwarnai oleh "pergolakan pemikiran", "penolakan," "pembaruan," maka, mau tidak mau, suka tidak suka, keadaan ini merupakan konsekuensi logis, sebagai "buah" rasionalitas dan kebebasan yang berjalin menjadi hakikat dirinya dan yang karenanya filsafat menemukan kehidupan "abadi". Fi is a f a t sebagai ilmu yang terus berkembang dan dijiwai oleh semangat kebebasan yang didasarkan pada rasionalitas yang kritis (tidak dogmatis) dan refleksif tidak mungkin menentukan suatu definisi filsafat sebagai satu-satunya yang paling benar. Sebab, jika ini yang terjadi, filsafat berarti telah "membiarkan dirinya" terjebak dalam pantangan yang telah dicanangkannya sendiri, yaitu telah bersikap dogmatis terhadap dirinya sendiri. Akibatnya, definisi yang dikemukakan para filsuf kurang lebih harus dilihat sebagai satu pendapat yang subjektif-didasarkan pada pemahamannya sendiri-dan terserah kita apakah hendak menerima definisi yang mana, atau bahkan membuat definisi sendiri.

Yang terpenting, untuk memperoleh pemahaman konseptual tentang filsafat, kita perlu kembali pada lima pengertian dasar yang disampaikan Angeles dan juga penjelasan ringkas yang disampaikan Bagus. Persoalan lain yang tampaknya menimbulkan kesulitan pemahaman adalah karena filsafat itu sendiri bersifat multidimensional, sementara di sisi lain, sebuah definisi dituntut untuk memberikan batasan pengertian secara tepat, jelas, dan singkat (Lanur 1983: 21). Dengan demikian, pertanyaannya adalah "mampukah sedikit kata yang digunakan dalam definisi itu dapat 
mengabstraksikan dinamika perubahan yang belum jelas akan menjadi seperti apa?" Itu masalahnya.

Akhirnya, definisi, sekalipun banyak kelemahan dan senantiasa tidak dapat tepat membatasi filsafat, sebaiknya diterima dan disikapi sebagai satu upaya untuk mengenali filsafat itu pada tahap awal.

\section{Argumen Filosofis bagi KeberadaAn Filsafat Nusantara}

Sejalan dengan pembicaraan tentang pertanyaan ada-tidaknya filsafat Jawa, Sunda, Batak, Minang, dan lain-lain di awal tulisan ini, beberapa argumen akan disampaikan berikut ini dengan menggunakan berbagai sudut pandang yang dimaksudkan agar dapat menemukan dasar berpijak yang dapat dipertanggungjawabkan secara filosofis.

\section{Sudut Pandang Definisi}

Dari berbagai definisi, terutama dari definisi khusus dari kamus filsafat, telah kita ketahui bahwa berdasarkan contoh-contoh definisi para filsuf Barat-Russell, Ayer, dan lain-lain-terlihat bahwa sejauh ini filsafat didefinisikan secara subjektif oleh tiap-tiap filsuf sehingga kesannya adalah bahwa tidak ada tolok ukur tertentu yang harus disepakati bersama secara pasti, kecuali bahwa filsafat itu berkaitan erat dengan suatu pemikiran rasional, khususnya di Barat, untuk memperoleh pemahaman akan diri, hidup, dan kehidupannya dan menarik makna bagi adanya dalam keseluruhan.

Terlihat juga dalam semangat filsafat Barat tersebut bahwa akal budi sebenarnya bersifat instrumental sebab yang sesungguhnya menjadi "tujuan akhir" dari kesibukan para filsuf dan siapa pun yang berfilsafat adalah hasil tertinggi yang di satu pihak ingin dicapainya, tetapi di pihak lain tak pernah sepenuhnya ada dalam "genggaman"-nya. Tujuan hasil akhir itu adalah "sesuatu" yang dibayangkannya sebagai "hal" yang seolah-olah mendasar, yang fundamental, yang "sepertinya" menjadi inti atau hakikat sesuatu dan sama sekali bukan demi tujuan rasio itu sendiri, an sich (pada dirinya sendiri). Dengan cara itu, filsafat bukan hanya milik Barat, melainkan milik manusia di belahan bumi mana pun sejauh berkemauan untuk merenungkan makna eksistensi dan tujuan hidupnya, termasuk or ang Jawa, Sunda, Batak, Minang, dan Badui.

Bahwa Barat menggunakan potensi manusiawi berupa akal budi untuk mengetahui berbagai hal dengan didukung pengamatan empirik, hal itu hanya persoalan tradisi saja, dalam arti bahwa Barat memang berakar pada cara berpikir Yunani Kuno. Akan tetapi, Barat adalah Barat dan Timur adalah Timur, dua kultur yang mempunyai latar belakang budaya yang berbeda. Oleh karena itu, masing-masing perlu dipahami berdasarkan segala keberadaan dirinya. Keberadaan tidak harus diartikan sebagai keburukan, tetapi begitulah kenyataan dirinya, itulah keunikannya. Di sana senantiasa dapat ditemukan suatu keotentikan sebagai yang "satu." Tentang hal ini, Bagus (1991: 86) telah menulis, "Salah satu ciri umum dari yang-ada ialah 
bahwa yang-ada itu benar. Yang-ada memiliki kebenaran sebagai sifat transendental. Tiga serangkai, yakni satu, benar dan baik, selalu ditemukan dalam pemahaman mengenai yang-ada."

Karena itu, Timur tidak harus menjadi Barat, pun sebaliknya. Jika Barat mengandalkan daya rasionalitas, Timur mempunyai cara pendekatan yang (sama sekali) berbeda, yakni bukan lagi mengandalkan akal budi, melainkan intuisi, hati sehingga wajar saja jika bukan pengamatan yang penting baginya, melainkan ketajaman rasa untuk mengetahui dan memahami segalanya. Perbedaan ini hanyalah soal pilihan, soal kebiasaan, dan, lebih dari itu, merupakan kepercayaan menyangkut dengan apa dan bagaimana manusia sampai pada apa yang dicita-citakannya dalam hidup. Sudah barang tentu masing-masing memiliki pilihan yang disesuikan dengan pandangan hidup, kepentingan, dan keyakinan yang telah terbangun di dalam dirinya selama ini. Jelaslah bahwa Barat tidak perlu menjadi seperti Timur, demikian pula Timur tidak perlu menjadi Barat. Yang diperlukan oleh masing-masing adalah bahwa apa yang menjadi tujuannya perlu dicapai dengan cara-cara yang dikembangkannya sendiri.

Sejalan dengan pembicaraan tentang keberadaan filsafat Nusantara, persoalannya bukan terletak pada semangat pembagian dikotomis bahwa pemikiran Barat itu filosofis (rasional, kritis, reflektif, mendasar, komprehensif), sedangkan Timur (Jawa) irasionalis, tidak kritis, tidak reflektif, tidak mendasar, dan tidak komprehensif. Persoalan ini tidak mungkin dapat dimengerti tanpa memahami perlunya prinsip identitas sebagai persoalan metafisis yang mendasari segala yang ada.

\section{Prinsip Identitas}

Pembicaraan tentang keberadaan filsafat Nusantara perlu didekati dari sudut pandang metafisis, khususnya dengan berdasarkan prinsip identitas. Prinsip ini mengatakan bahwa "being is being" ("yang-ada adalah yangada') (Gerard Phelan), bahwa "each being is what it is," ('setiap benda adalah apa adanya') (Maritain) atau dapat juga berarti "wohat exist exists" (Bagus 1991: 81). Mengingat pemikiran Jawa juga bagian dari realitas - sementara keberadaan realitas berdasarkan pada satu prinsip, yaitu prinsip identitas, yang menjadi prinsip tertinggi dalam rangka dan dalam upaya memahami sesuatu-, dasar keberadaan filsafat Jawa perlu didasarkan pada prinsip identitas untuk memperoleh pengesahan dirinya sebagai sesuatu dengan identitas tertentu yang unik.

Dari kutipan di atas sebenarnya telah jelas bahwa pada dasarnya setiap yang-ada (bereksistensi) adalah dirinya sendiri dan dengan demikian dibedakan dari lainnya. Jika "yang-ada" pada dasarnya adalah dirinya sendiri, setiap hal sebagai bagian dari yang ada harus dilihat sebagai dirinya sendiri. Sebagai dirinya sendiri jelas mengisyaratkan bahwa keberadaannya sama sekali tidak ditentukan oleh keberadaan yang lainnya dan tidak harus seperti apalagi mengikuti dan mengidentikkan diri dengan "ada-yang lain" itu. Jika pelanggaran terhadap prinsip identitas terjadi, "yang-ada" yang 
seharusnya unik itu dengan sendirinya kehilangan identitas dirinya dan tak dapat dipikirkan sebagai bagian dari "yang-ada", yang memang seharusnya berbeda dari apa pun lainnya.

Sebagai dirinya, ia harus sesuai dengan kodratnya. Dengan kata lain, dapat dikatakan bahwa setiap yang ada memiliki hakikatnya sendiri, hakikat yang tertentu (natura determinata). Karena itu, semestinya dapat dipahami keunikan dan keotentikan dari setiap "yang-ada". Lebih daripada itu, perlu dihormati keberadaannya karena memang tak mungkin "yangada" itu sama dengan "yang-ada" lainnya. Kalaupun ada kesamaan, kesamaan di antara semua "yang-ada" hanya secara vertikal karena segala sesuatu ("yang-ada") kembali kepada "yang-satu", tetapi masing-masing senantiasa berbeda dari lainnya jika dilihat dalam hubungannya satu dengan lainnya secara horizontal.

\section{Sudut Pandang Hakikat Kemanusiaan}

Dengan penekanan yang berbeda atas potensi rohani manusiawi yang menjadi andalannya, hendak dikatakan di sini bahwa persoalan perbedaan Timur dan Barat terletak pada potensi manusiawi mana yang dijadikan andalan dalam rangka menggapai sang Ada yang tertinggi itu: apakah dengan mengandalkan akal budi ataukah intuisi. Kata mengandalkan mengandung maksud bahwa pertimbangan rasional tidak sama sekali dikesampingkan dalam segala hal (urusan) di Timur-dalam hal ini filsafat Nusantara. Ia hanya tidak dipentingkan sebagai satu-satu-nya jalan menuju "kebenaran yang dicarinya". Sebab, jika benar bahwa Timur sama sekali tidak menghargai rasionalitas, tentu kenyataan ini akan janggal dan bersifat kontradiktif dengan hakikat kemanusiaan yang inheren di dalam dirinya, disadari atau tidak, sebagai makhluk yang "metafisis", makhluk yang tak pernah puas untuk berhenti pada hal yang konkret yang aktual, tetapi berusaha mencari sesuatu di balik yang ada, melampaui yang fisik (meta ta physica) dan mencari sesuatu yang tersembunyi. Hal itu karena karena manusia tak puas untuk membiarkan dirinya terbelenggu dalam kenyataan hidupnya yang terkini. Jelas terlihat bahwa manusia hendak "keluar" dari keterbatasan fisiknya sebagai salah satu bentuk pengungkapan transendensi manusia.

Dari kecenderungan manusiawi tersebut dapat disimpulkan bahwa manusia adalah makhluk yang tidak sepenuhnya terbelenggu oleh keterbatasan fisiknya. Manusia bukan sepenuhnya kodrati alami, tapi seluruh eksistensinya melebihi kodrat (homo additus naturae), yang tak mau terbelenggu oleh dan dalam ketubuhannya atau kejasmaniannya. Lebih daripada itu, manusia adalah makhluk yang mampu berpikir dan bernalar sehingga cepat atau lambat, suka tidak suka, direncanakan atau tidak, sadar atau tidak, pada akhirnya akan melihat atau menemukan ide mengenai "yang-ada", "sesuatu yang mutlak", "sang realitas". Hal itu karena manusia adalah makhluk rohani yang ingin melampaui "dirinya" sendiri (Bagus 1991: 4-5). 
Dengan penjelasan filsafati tentang kodrat manusia yang bukan sematamata jasmani, tetapi juga rohani, manusia senantiasa berpikir dan melakukan transendensi atas kenyataan hidupnya. Amat sulit dibayangkan bahwa filsafat akan terpisah dari kehidupan manusia. Karena itu pula, sebagai konsekuensi logis, harus dikatakan bahwa manusia Indonesia juga berada dalam pencarian filosofis/filsafati akan dirinya, akan sesuatu yang dianggapnya bermakna bagi dirinya, bagi hidupnya. Persoalannya adalah seperti apakah pemikiran filosofis orang Jawa, Sunda, Minang, Batak, dan suku yang lain? Ini yang selanjutnya harus ditunjukkan, harus dirumuskan agar menjadi jelas.

\section{Evaluasi Kritis}

Berbagai sudut pandang telah dikemukakan di muka dalam rangka memperoleh pendasaran filosofis atas keberadaan filsafat Nusantara. Dari keseluruhan uraian yang telah dikemukakan, dapat ditarik suatu kesimpulan bahwa setidaknya terdapat dua sumber pengetahuan yang perlu dievaluasi kembali jika hendak dilihat secara makro.

Pertama, memang terdapat kerancuan dalam hal pilihan kata yang semestinya digunakan untuk menamai suatu pengertian yang bersifat kefilsafatan. Kerancuan agaknya terjadi karena konsep-konsep yang mendasari atau membangun suatu istilah sebagai dirinya sendiri kurang dipahami dengan baik. Akibatnya, terjadi suatu keadaan tumpang tindih, salahkaprah, dan kebingungan sehingga wajar jika kemudian kekacauan pengertian pun tidak terhindari.

Kedua, filsafat yang tumbuh di Yunani dan berkembang pesat di Barat hingga kini juga tidak berdiri di atas satu dasar yang konstan dan kaku apalagi ekstrem. Sebagai contoh, tak ada kesepakatan apa pun sehubungan dengan pemahaman tentang filsafat itu apa. Sebagaimana yang terjadi pada para filsuf Barat, sikap yang perlu dikembangkan agaknya kemauan berfilsafat. Hal itu jauh lebih berguna daripada mempersoalkan filsafat itu apa, apalagi kita mengetahui bahwa kegiatan berfilsafat itu belum selesai, masih terus dilakukan di belahan bumi mana pun dalam rangka kehidupan yang semakin manusiawi dan terus dimanusiawikan. Karena itu, yang jauh lebih penting bukan pertanyaan "apakah filsafat Jawa, Minang, Batak, Sunda itu ada atau tidak?", tetapi pertanyaan "bagaimana kita semua itu sebagai seorang manusia dengan latar belakang budayanya sendiri-sendiri berfilsafat di dalam hidupnya?" dan "untuk apa kita semua berfilsafat?".

Ketiga, ditinjau dari sudut pandang metafisik, ada-tidaknya filsafat Jawa tidak dapat didasarkan pada satu ukuran-Barat-, apalagi ukuran tersebut dikenakan secara ketat untuk menghakimi suatu "produk" budaya yang berasal dari lingkungan budaya yang berbeda, seperti Sunda, Jawa, Minang, Batak, dan Bugis. Jika hal itu dilakukan, pluralitas "yang-ada" akan diingkari dengan sendirinya sehingga jelas merupakan satu pelanggaran terhadap prinsip identitas yang melandasi segala "yang-ada". 


\section{DAFTAR ACUAN}

Angeles, Peter A (1981), Dictionary of Philosophy. New York: Barnes \& Noble Books. Anh, To Thi (1985), Nilai Budaya Timur dan Barat: Konflik atau Harmoni. Jakarta: Gramedia.

Bagus, Lorens (1991), Metafisika. Jakarta: Gramedia Pustaka Utama.

(1992), "Ludwig Wittgenstein: Masalah Bahasa dan Makna", dalam Para Filsuf Penentu Gerak Zaman, FX. Mudji Sutrisno \& F. Budi Hardiman (ed). Yogyakarta: Kanisius. - (1996), Kamus Filsafat. Jakarta: Gramedia Pustaka Utama.

Beekman, Gerard dan A.A. Rivai (1984), Filsafat Para Filsuf Berfilsafat. Jakarta: Erlangga.

Bertens, K (1990), Filsafat Barat Abad XX: Inggris-Jerman. Jakarta: Gramedia. (1992), Sejarah Filsafat Yunani: Dari Thales ke Aristoteles. Yogyakarta: Kanisius. Ciptoprawiro, Abdullah (1986), Filsafat Jawa. Jakarta: Balai Pustaka.

Echols, John M. dan Hasan Shadily (1989), Kamus Inggris-Indonesia: An English-Indonesian Dictionary. Jakarta: Gramedia.

- (1990), Kamus Indonesia-Inggris: An Indonesia-English Dictionary. Jakarta: Gramedia.

Heuken SJ, Adolf (1987), Deutsch-Indonesisches Woerterbuch. Kamus Jerman-Indonesia. Jakarta: Yayasan Cipta Loka Caraka dan Gramedia.

Jung, Carl Gustav (1987), Menjadi Diri Sendiri: Pendekatan Psikologi Analisis. Jakarta: Gramedia.

Krause, Erich-Dieter (1985), Woerterbuch Indonesisch-Deutsch. Leipzig: VEB Verlag Enzyklopaedie.

Lanur, Alex, OFM (1983), Logika. Yogyakarta: Kanisius.

Leahy, Louis (1989), Manusia, Sebuah Misteri: Sintesa Filosofis tentang Makhluk Paradoksal. Jakarta: Gramedia.

Magnis-Suseno, Franz (1984), Etika Jawa: Sebuah Analisa Falsafi tentang Kebijaksanaan Hidup Jawa. Jakarta: Gramedia.

Peursen, C.A. van (1980), Orientasi di Alam Filsafat. Jakarta: Gramedia.

Poerwadarminta, W. J. S (1984), Kamus Umum Bahasa Indonesia. Jakarta: PN Balai Pustaka.

Windelband, Wilhelm (1958), A History of Philosophy: Greek, Roman, and Medieval. Vol. I. New York: Harper \& Brothers Publishers. (1958), A History of Philosophy: Renaissance, Enlightenment, and Modern. Vol. II. New York: Harper \& Row. 